\title{
PHILOSOPHY
}

\section{MORPHING OF MASS CONSCIOUSNESS AND REMYTHOLOGIZATION IN SITUATION OF GLOBALIZATION}

\author{
Professor Karina Ivanova, \\ Associate professor Yana Balabay, \\ Associate professor Oleg Sadovnikov, \\ Ukraine, Kharkiv, National University of Pharmacy, \\ Philosophy and Sociology Department
}

DOI: https://doi.org/10.31435/rsglobal_sr/31032020/6996

\section{ARTICLE INFO}

Received 13 January 2020

Accepted 05 March 2020

Published 31 March 2020

\section{KEYWORDS}

myth, mass consciousness, public consciousness, globalization, space, time, morphing, remythologization.

\begin{abstract}
The article is devoted to the changes in society and public consciousness in the conditions of globalization. Phenomenon of mass consciousness and its differences of public consciousness are analyzed in the article. An important point to disclose a new rationality is an understanding of the connection that can give unity to the consciousness of an individual person and to a certain social group is a myth. Mythology in conditions of globalization processes can be defined as remythologization. Myth as a part of mass consciousness becomes an attractive element for the manipulation of mass consciousness, as an instrument to solve political ambitions, to manage groups of people. It can be observed in the process of myth-creation, in the formation of "pictures of the world" and ideologies, in the development of informational and psychological wars, in the formation of public opinion.
\end{abstract}

Citation: Karina Ivanova, Yana Balabay, Oleg Sadovnikov. (2020) Morphing of Mass Consciousness and Remythologization in Situation of Globalization. Science Review. 3(30). doi: 10.31435/rsglobal_sr/31032020/6996

Copyright: (C) 2020 Karina Ivanova, Yana Balabay, Oleg Sadovnikov. This is an open-access article distributed under the terms of the Creative Commons Attribution License (CC BY). The use, distribution or reproduction in other forums is permitted, provided the original author(s) or licensor are credited and that the original publication in this journal is cited, in accordance with accepted academic practice. No use, distribution or reproduction is permitted which does not comply with these terms.

Introduction. Globalization as a process of world transformation into an economic, informational and multicultural unity has become a reality as a main transforming factor of society. Globalization processes have not only an economic nature, although the development of the world economy has brought society to a new level. These processes are influenced by the development of international trade and investment policy at micro and macro levels, the strengthening of migration, and a new attitude to information, knowledge and ideas. Transformations of economy also affected other areas of society (social, political, spiritual) requiring its reorganization. At the same time, there was a clash of usual norms of society with innovative and not formed positions aimed at creation of a single, holistic and universal world.

These processes are connected to the exacerbation of social and humanitarian problems that have ceased to be local in the context of globalization. Anthony Giddens points to a management system as a "slipping out of the hands" affects both world-wide events and in everyday life. David Held, analyzing global transformations speaks about new forms of existence of national states and national interests that can no longer compete with global interests. The studies of Roland Robertson, who first used and coined the concept of "globalization," points at the transformation of human consciousness of the modern world, changing under the influence of awareness of globalization processes, with the "compression of the world" and awareness of this process. 
There is a variety of concepts describes the models of global society. It includes: the worldsystem model of Immanuel Wallerstein, the network society concept of Manuel Castells, the concept of globalization of cultures of Roland Robertson. Here we use the definition of globalization expressed by Leonid Ionin: "Globalization is the universal distribution of homogeneous cultural patterns and the gradual creation of a unified global system of economics and social management, which inevitably occurs due to the abstraction from national traditions and characteristics" [1; p. 228].

The formation of a global structure of economic, political and cultural relations unites the society into a single system, developing tolerant approaches to solving acute problems. At the same time the society with a tendency to unity still has its social differentiation of economic, political, professional, cultural, religious nature that is an inhibitory background for globalization unity.

The division of society according to the principle proposed by Henry Bergson and developed by Karl Popper, into an open society and enemies of an open society, shows the complexity of the processes of forming an open society, acceptable for the development and existence of a globalized society. According to K. Popper, an open society is a democratic type of society characterized by pluralism, tolerance, dynamic social mobility, the adoption of innovations, with the centralized position of an individual characterized by rationality, based on critical thinking and rejecting taboo. The society of enemies of an open society, which K. Popper often defines as closed or totalitarian one, hasn't lost its strength of opposition.

Karl Popper also pays attention to the fact that the collapse of a closed society or the development of an open society can lead to an abstract society in which people practically don't meet face to face. This society is impersonal, anonymous, with the presence of surrogate social roles and relationship; this is a society of loneliness. It's clear enough that Karl Popper makes it clear that abstract society is very close to the current state.

Main results. Modern society is often defined as a transitional one, but the transitional stage involves the destruction of previously existing structures and the beginning of the formation of new social relations when they strive for final formation. It means that a previously existing society with its social structures and institutions is a past and new social forms are only being formed. Today society as a system possessing the qualities necessary for its existence (integrity, ligaments, orderliness, management, purpose and self-organization) doesn't exist. We can talk about individual societies - separate systems, but not about a single society as a totality of people united by historically determined social forms of life and activity. In united social reality it is more appropriate to talk about a mass as an organized community with the help of external factors - a certain idea, a mood, an opinion, a political force, and the influence of a leader. A mass can consist of people of various social groups and strata, adopting a certain unified set of norms, values and attitudes [2]. A mass, various mass associations and movements are increasingly beginning to influence social life and changes in society itself. "There is a phenomenon that, fortunately or unfortunately, defines modern European life. This phenomenon is a complete seizure by a mass of social power ... It is called the uprising of the masses." [3; p. 15].

If society has social consciousness, so mass has mass consciousness as a consciousness of masses, as a way of reflecting and evaluating the social being. Based on studies of mass consciousness, reflected in the monograph of Boris Grushin [4], we can highlight the characteristic features of mass consciousness. Mass consciousness has a complex, syncretic character, a spontaneously institutionalized nature and the absence of a clear structure. It has a mosaic, torn and inconsistent nature manifested by the interaction and contradiction of conservatism and the tendency to follow fashion, the resistance of new information and its susceptibility, the choice is made with orientation to feelings and moods.

The content of mass consciousness is based on the simplification of perception, which can be traced at levels of public consciousness, both ordinary and theoretical, both in social psychology and in ideology. At the same time, it is difficult to draw a clear line between the levels. Mass consciousness borrows some elements from the forms of social consciousness (political, legal consciousness, morality, religion, aesthetic consciousness, science, philosophy, etc.), due to which mass consciousness is heterogeneous and diverse and uses archetypes, stereotypes, behavioral norms and attitudes. The content of mass consciousness can be transformed under the influence of moods, emotions, rumors, mass media and the objective conditions of social life. The individual consciousness in such conditions begins to transgress being out of social or mass consciousness influence. 
The development of mass consciousness and wandering individual consciousness causes an increase of irrationality in its two aspects: in the negative one - as the initial movement to the rational possible for reflection; and in the positive one - as impossible for cognition. There is a clear tendency in modern philosophy towards a broad interpretation of the concept of rationality understood as a method of cognition based on reason; like some kind of structure; as an attribute of civilization, at the same time, the moment of the emergence of rationality and its further genesis take place in the fight against myth, and, moreover, at present the myth, as part of the irrational, begins to approach rationalism [5]. A "new rationality" is being formed, since the type of rationality fostered by the European tradition on the basis of the cult of reason and science undergoes modification, becoming closer to irrationality.

An important point to disclose a new rationality and transgressive consciousness is an understanding of the connection which can give integrity and unity to the consciousness of an individual person and a certain social group, while maintaining mobility adapted to transgression. It can be a myth with its special properties such as: figurativeness, associativity, anthropomorphism, communicativeness, supernatural character, paradigm, tribal affinity and own mythological time. In this case the myth appears not just as a story, but primarily as a generalized reflection of reality in the form of sensory representations as a life reality, an oral personal story. The same definition gives Alexei Losev in "Dialectics of Myth". "When a myth and a mythology become an object of philosophical reflection, rather than anthropology, ethnography, or any specific descriptive discipline, the myth is almost not permeable. Don't forget that the mythologist, describing some myths, inevitably describes them in a mental context of the myth of himself" [6].

The myth doesn't exist separately; it can't act in isolation of the world, a society, and a man. "Myths affirmed the value system adopted in this society, supported and sanctioned certain norms of behavior ... Separated myths gave explanations for individual norms and rules. But their complex, that is, mythology is focused on overcoming the fundamental antinomies of human existence, on the harmonization of personality, society and nature" [7, p. 54]. According to this approach mythology as a chain of myths can be defined as means and method of perception and explanation of the world. Mythology appears as one of the types of consciousness, and myths are structures of consciousness that require interpretation. Myths form ideas about the picture of the world and its individual parts: nature, man, society; determine the nature of social ties, morality, attitudes to law; explain a lot of what a person meets. This is a system in which you can find answers to all possible questions. At the same time, mythology becomes a way of perception and orientation in the world, a clear knowledge, a mythological paradigm.

The mythological component in public and individual consciousness held its own position in all epochs of mankind history. The share of mythology could increase or decrease in interaction with other forms of consciousness, but its action has always been manifested [8;9].

Mythologization of consciousness continues at the present time, while the myth, using its adaptive capabilities, has acquired new features and properties. This is no longer "naive" inventions about gods and heroes, but "a producing unconscious, which requires to be expressed and strive to express itself", as defined by Gilles Deleuze [10; p. 46]. Today, mythology manifests itself as an irrational system of human relations with the world. And the myth today according to the interpretation of Leonid Ionin: "it is a bright and genuine reality, perceived, material, bodily reality, a totality of not abstract but experienced categories of ideas and life, which has its own truth, authenticity, regularity and structure, and at the same time containing the possibility of detachment from the normal course of events, the possibility of the existence of a hierarchy of being" [11, p. 108].

Modern mythological consciousness is not aimed at creating pretentious images of gods, spirits, demons, monsters, which interfere with the world order and determine the development of the world and society, controlling a person's life. Modern mythological consciousness is based on developed abstract thinking, in contrast to the thinking of earlier eras. The mythical image no longer needs a clear completeness expressed in the form of a myth-story, myth-ritual, myth-mystery or mythimage. A modern person who falls under the power and charm of a myth needs a sense of ownership in creating a myth, attracting personal imagination, personal imagery, personal empathy, even if we are talking about old and even ancient myths, and even more so the complicity is revealed in modern myths - social, political, religious, pseudoscientific.

The strengthening of the mythological influence on modern society and consciousness should be considered not only as the mythologization of modern consciousness as a process of strengthening mythology displaces other forms of consciousness while competing with them, but as a new stage of 
development of mythology that assimilates, implements and transforms other forms consciousness. Such a new existence of mythology can be defined as remythologization.

Remythologization is often associated with the return and increasing of attention to ancient myths, the restoration of myths, the actualization of mythological consciousness - it can be recognized as true if you do not take into account that the myth, having a wide interpretation, is able to fit into various cultural contexts and this is a property of myth - not its new form of existence.

Mythology as a collection of myths also has some possibilities for renewal. The appearance of neopagan and some syncretic religions also becomes the result of adaptive manifestations of mythology. All these changes can be more correctly called as restoration of mythology and used the term neomythology means the restoration of mythological systems with the introduction of a new, more modern content, definition and semantic sense. Neomythology doesn't change consciousness, but fills the gaps left by science, religion, philosophy. Neomythology can be considered as one of the moments of the development of remythologization.

Remythologization takes place at critical historical moments of a global character or the periods that can influence global changes. One of such moments should be recognized as an "axial time" allocated by Karl Jaspers. The changes took place during this period led to national structuring and urban society, radically transforming the consciousness that made the transition from the total power of myth to religion and philosophy through rationalization. At the same time mythology went on its development at another level, adapting and sometimes connecting with religion and philosophy.

The scientific revolution of the $17^{\text {th }}$ century can be considered as the second historical moment. The scientific revolution brought science into a new level opening the possibility to introduce its achievements into the production and development of new branches. The significance of the scientific revolution is widely reflected in various studies of philosophical, historical, sociological and cultural character. A comprehensive approach to understand the results of the scientific revolution was carried out by Alvin Toffler, who defined this historical moment as the second wave of the development of mankind, which led to the industrial revolution and industrial society. At the same time, Alvin Toffler notes that the second wave is characterized by the rapid speed of its growth.

Analysis of science development attempted by the positivists to rid science of metaphysical and mythological strata had led to the conclusion that science is not able to oppose the false or pseudoscience in proper opposition. And it has become a favorable factor for the inclusion of mythological component into some scientific theories of the social plan and creation of mythological systems with the inclusion of elements of science. Mythology has acquired the possibilities of a science-like existence.

Currently, we are in the next historical moment of social transformations. Until now, the main characteristics of society reflected the end of its history, the regressive effects of technocracy, decadence and crisis of culture, the collapse of traditions and morality. The definitions featured the prefix post - post-industrial, post-economic, post-modern society, post-human, post-Soviet or posttotalitarian. Now, the affirmative definitions of the individual forces that drive society connected to the headline of modern society, such as the information society, consumer society, civil society, and other definitions - are more and more clearly manifested.

The favorable field for remythologized systems is expanding.

The historical moment of present-day society conditions can be defined as a global society. Expanding the understanding of globalization as a single system of economy, social management and cultural patterns, the development and functioning of a mass society with its consciousness has a subjectively tuned mosaic character, prone to remythologization for clarification of existential entities. This statement taken as a hypothesis opens up some possibilities for finding properties of remythologized mass consciousness in globalization of modern society and the causes of this phenomenon.

The formation of the global world means a single space-temporal existence, in which the existence of this world unfolds. Space and time in the conditions of increasing globalization are acquiring certain difficulties for traditional perception and understanding, primarily because of its global nature - the inclusion of various perceived subspaces - real, perceptual, and conceptual - in their morphing (visual perception, in which the effect of smooth transformation of the object into the another one) weave.

With the development of modern engineering and technology, distance-spatial representations are updated. 
The notions of distance and space can no longer be perceived only as physical changes in the sphere of objective reality. Their perception is complemented by psychological perceptual reflections of the properties of space and conceptual descriptive models that combine in consciousness, forming a single perception of spatial attributes. In this case a person doesn't lose the reality of the definition of space, but this reality is supplemented by other possibilities of perception of space.

High-speed comfortable transport, a variety of additional services makes traveling not only convenient, but it changes the reality of determining distances. Distances begin to be determined not in terms of the distance itself - miles, kilometers, but in units of time, comfort, safety, necessary resources. It is possible during the trip not to deprive you of the usual activities. The universality of transport system, a sign system, terminals smooth out the perception of new impressions moving for large distances. Modern technologies that simulate virtual reality and simulate interaction with the environment connect a person to a new spatial world that goes beyond reality, but is perceived as part of reality.

Electronic communications, the creation of systems of a single complex of services, banking services, hotel services, satellite television broadcasting, the activities of international trade and industrial corporations, various international communities, migration make it possible to perceive space as unshared. Psychologically, the space in which a person acts can be perceived as "Oecumene" for the ancient Greek - a familiar, mastered space, in contrast to "alien", "not mine" territories. But Oecumene can exist when there are dangerous and alien territories, and globalization destroys "alien" territories - Oecumene is now everywhere. A space arises whose boundaries are not captured or perceived in the unity of real, perceptual and conceptual spatial definitions. The new vision of space resembles the mythological unity of the world in which there is a space of gods, demons and people, but they all merge together in a single world consisting of separate but interacting worlds. Globalization doesn't restore the mythological spatial system, but forms much more complicated spatial constructions of real, virtual, informational, perceptual and conceptual parts.

Similar processes with a change in space occur with the perception of time. First of all, attention should be paid to the basic properties of mythological time - the cyclical nature and orientation towards the Great Time. The cyclic character of time is manifested in the alternation of demiurgical creation and the cessation of existence, which gives rise to a new creation. The movement from creation to the new world through destruction can develop according to two eschatological scenarios. The first option is the Golden Age version: the times of creation were better, but were replaced by times bearing trials and tribulations, after which a happy and blessed New Age will come back or start again. This option is used in many modern religions, not only in Christianity or Islam. This option is noticeable in Marxist constructions. This story is also used in futuristic concepts of a positive context. It is actively manifested in the political struggle. The second option is the Ragnarok variant (rock of the gods, can be translated as "twilight of the gods" or "death of the gods"): the death of the whole world with the preceding war and cataclysms and the subsequent birth of the New World, into which only some selected minority can create a New Generation in the best the world. This option is reflected among pessimistic futurologists, in some modern religions, in the New Age moods, in fantastic works, in cinema, and in computer games.

Entering the Great Time is supposed through holidays, which are dedicated to events related to key moments of history, both past and future events, with the celebration of heroes whose actions are supposed to be a model for repetition. Considerable role belongs to the "sorted" the history, ideology and activities of politicians. Separately it is necessary to put the science fiction, fantasy, pseudo-scientific creation.

The visualization and "feeling" of the events of the Great Time, for their consolidation by mythological consciousness, is carried out through a ritual, mystery, as repeatedly indicated by James George Frazer, Eleazar Meletinsky, Alexei Losev, Evgeny Torchinov, Mircea Eliade. The embodiment of a myth has been preserved, but a more powerful effect is exerted on consciousness through various achievements of modern mass culture. The leading role belongs to television and cinema, where the future, the present and the past intersect. Futuristic or historical films fill our present time with visible and real images. Using computer technology allows to create the most fantastic images. Various ancient gods, fairies, gnomes, dragons, heroes of legends and myths, modern superheroes realistically appear on the screen. Talk shows of a mystical, sacred and pseudoscientific nature introduce the viewer into a mysterious world; "Eyewitnesses" and "accomplices" of mystical events; speeches by researchers of Atlantis, Shambhala, lost knowledge of great civilizations and cosmic contacts complement credibility. 
Conclusions. Socio-philosophical studies provide an opportunity to determine the modern narrative of remythology, its presence and practical impact on a globalized society in which myth becomes a mean of social orientation, one of the ways to explain the world. At the same time, myths, acting on an individual level, acquire a mass character in a mass society. Becoming a part of consciousness, myths become an attractive element for the possibilities of manipulating of mass consciousness, which gives rise to the creation and implementation of myths of artificial origin to solve certain political ambitions, to manage groups of people in order to achieve the most diverse goals. It can be observed in the process of myth-creation, in the formation of "pictures of the world" and ideologies, in the development of information and psychological wars, in the distortion and destruction of information, in the formation of public opinion and social meanings.

\section{REFERENCES}

1. Ионин Л.Г. Социология культуры: путь в новое тысячелетие: учебное пособие: Изд. 3-е, перераб. и доп. /Л. Г. Ионин. Москва: Логос, 2000. 432.

2. Кузнецов Д.В. Массовое сознание в современном российском обществе: Социально-философский анализ: автореф. дис. ... канд. философ.наук. Москва, 2005.

3. Ортега-и-Гассет Х. Восстание масс. Москва: ООО «Изд-во АСТ», 2002. 509 с.

4. Грушин Б. А. Массовое сознание: Опыт определения и проблемы исследования. Москва: Политиздат, 1987. $368 \mathrm{c.}$

5. Гуревич П. С. Поиск новой рациональности (по материалам трех всемирных конгрессов). Москва: ИФ РАН, 1995. С. $209-224$.

6. Мифология и сознание современного человека: [лекции проф. Лондонского университета Пятигорского А.М. прочитанная 21 февраля в клубе-литературном кафе «Bilingua» в рамках проекта «Публичные лекции «Полит.py» URL: http://polit.ru/article/2006/03/02/pjatigorsky/.

7. Мелетинский Е. М. Поэтика мифа. Москва: Наука, 1976. 399 с.

8. Найдыш В. М. Философия мифологии от античности до эпохи романтизма. Москва: «Гардарики», 2002. $554 \mathrm{c}$.

9. Найдыш В. М. Философия мифологии. XIX - начало XXI вв. Москва: «Альфа-М», 2004. 544 с.

10. Делез Ж., Гваттари Ф. Анти-Эдип: Капитализм и шизофрения. Екатеринбург: У-Фактория, 2007. 627 с.

11. Ионин Л. Г. Социология культуры: учеб. пособие для вузов. Москва: Изд. дом ГУ ВШЭ, 2004. 427 с.

12. Васильева Н.А. Философские и экономические аспекты мировой политики. Санкт-Петебург: Изд-во СПб. ун-та, 2006.

13. Кастельс М. Информационная эпоха. Экономика, общество и культура / Пер. с англ. под науч. ред. О.И. Шкаратана. Москва: ГУ ВШЭ, 2000. 608 с. 